\title{
Supplementation of grazing suckling beef calves receiving different energy sources
}

\section{Suplementação de bezerros de corte lactentes em pastejo com diferentes fontes energéticas}

\author{
Josilaine Aparecida da Costa Lima ${ }^{1 *}$; Mário Fonseca Paulino²; Edenio Detmann²; \\ Luciana Navajas Rennó2; Henrique Jorge Fernandes ${ }^{3}$; Aline Gomes da Silva ${ }^{4}$; \\ Sidnei Antonio Lopes ${ }^{4}$; David Esteban Contreras Marquez; \\ Leandro Soares Martins ${ }^{4}$; Felipe Henrique de Moura ${ }^{5}$
}

\begin{abstract}
The aim of this study was to evaluate the effect of different energy sources - corn, sorghum, and wheat bran - on performance, intake, digestibility, and nitrogen utilization efficiency of beef calves subjected to creep feeding. Thirty-four calves (12 males and 22 females) with initial age and weight of four months and $108 \pm 3.9 \mathrm{~kg}$, respectively, were used in a randomized-block experimental design with four treatments and two blocks (males and females). Treatments were control (MM), a mineral mixture ad libitum; corn $(\mathrm{C})$; corn + sorghum $(\mathrm{C}+\mathrm{S})$; and corn + sorghum + wheat bran $(\mathrm{C}+\mathrm{S}+\mathrm{WB})$. Supplements contained approximately $20 \%$ crude protein (CP), and were fed in the amount of $0.5 \%$ of body weight. Supplemented animals had higher performance $(\mathrm{P}<0.05)$ when compared with those on treatment MM. Supplementation increased $(\mathrm{P}<0.05)$ the intakes of dry matter $(\mathrm{DM})$, organic matter $(\mathrm{OM})$, crude protein (CP), neutral detergent fiber corrected for ash and protein (NDFap), non-fibrous carbohydrates (NFC), digestible neutral detergent fiber (dNDF), and digestible organic matter (dOM). The digestibility of NFC was higher $(\mathrm{P}<0.05)$ in the supplemented treatments. The $\mathrm{C}+\mathrm{S}$ and $\mathrm{C}+\mathrm{S}+\mathrm{WB}$ treatments provided increased digestibility $(\mathrm{P}<0.05)$ of $\mathrm{OM}, \mathrm{CP}$, and NDFap. The synthesis of nitrogen compounds was higher $(\mathrm{P}<0.05)$ in animals on treatment $\mathrm{C}$ as compared with those on the other supplemented treatments. Animals on treatments $\mathrm{C}+\mathrm{S}$ and $\mathrm{C}+\mathrm{S}+\mathrm{WB}$ had higher $(\mathrm{P}<0.05)$ nitrogen utilization efficiency compared with those on the other treatments. Concentrate supplementation improved the animal performance. The use of other energy sources (sorghum or wheat bran) in association with corn is recommended for suckling calves.
\end{abstract}

Key words: Cattle. Corn. Forage. Nitrogen. Performance.

${ }^{1}$ M.e em Zootecnia pela Universidade Federal de Viçosa, UFV, Viçosa, MG, Brasil. E-mail: josilainelima.zootecnia@yahoo. com.br

2 Profs. Drs., Departamento de Zootecnia, Universidade Federal de Viçosa, DZO/UFV, Viçosa, MG, Brasil. E-mail: mpaulino@ ufv.br; detmann@ufv.br; lucianarenno@ufv.br

${ }^{3}$ Prof. Dr., Universidade Estadual do Mato Grosso do Sul, UEMS, Aquidauana, MS, Brasil. E-mail: henrique.uems@hotmail. com

${ }^{4}$ Discentes do Curso de Doutorado do Programa de Pós Graduação em Zootecnia, Departamento de Zootecnia, DZO/UFV, Viçosa, MG. E-mail: alinegomesdasilva@rocketmail.com; sidnei.lopes@ufv.br; davidestebas@hotmail.com; leandros_martins@yahoo. com.br

${ }_{5}^{5}$ Discente de graduação do Curso de Zootecnia, Departamento de Zootecnia, DZO/UFV, Viçosa, MG. E-mail: felipe.moura@ ufv.br

* Author for correspondence 


\section{Resumo}

O objetivo deste trabalho foi avaliar o efeito de diferentes fontes energéticas, milho, sorgo e farelo de trigo, sobre o desempenho, o consumo, a digestibilidade aparente total dos constituintes da dieta e a eficiência de utilização dos compostos nitrogenados em bezerros de corte submetidos ao creep feeding. Foram utilizados 34 bezerros lactentes ( 12 machos e 22 fêmeas) com idade e peso médio inicial de quatro meses e $108 \pm 3,9 \mathrm{~kg}$, respectivamente. O experimento foi conduzido em blocos casualizados com quatro tratamentos e dois blocos (machos e fêmeas). Os tratamentos foram: controle (MM), fornecimento de mistura mineral ad libitum aos animais; milho $(\mathrm{M})$; milho + sorgo $(\mathrm{M}+\mathrm{S})$ e milho + sorgo + farelo de trigo $(\mathrm{M}+\mathrm{S}+\mathrm{FT})$. Os suplementos continham aproximadamente $20 \%$ de proteína bruta $(\mathrm{PB})$ e foram fornecidos na quantidade de $5 \mathrm{~g} \mathrm{~kg}^{-1}$ do peso corporal. Os animais suplementados apresentaram maior $(\mathrm{P}<0,05)$ ganho de peso quando comparados com os animais do tratamento MM. A suplementação aumentou $(\mathrm{P}<0,05)$ os consumos de matéria seca $(\mathrm{MS})$, matéria orgânica $(\mathrm{MO}), \mathrm{PB}$, fibra em detergente neutro corrigida para cinzas e proteína ( $\mathrm{FDNcp}$ ), carboidrato não fibroso (CNF), fibra em detergente neutro digerida (FDNd) e matéria orgânica digerida (MOD). A digestibilidade aparente total do CNF foi maior $(\mathrm{P}<0,05)$ nos animais suplementados. Os tratamentos $\mathrm{M}+\mathrm{S}$ e $\mathrm{M}+\mathrm{S}+\mathrm{FT}$ apresentaram maior $(\mathrm{P}<0,05)$ digestibilidade aparente total da MO, PB e FDNcp. A síntese de compostos nitrogenados foi maior $(\mathrm{P}<0,05)$ nos animais do tratamento $\mathrm{M}$, em relação aos demais tratamentos suplementados. Os animais dos tratamentos $\mathrm{M}+\mathrm{S}$ e $\mathrm{M}+\mathrm{S}+\mathrm{FT}$ apresentaram maior $(\mathrm{P}<0,05)$ eficiência na utilização do nitrogênio quando comparados aos demais tratamentos. A suplementação concentrada melhorou o desempenho dos animais. Recomenda-se a utilização de outras fontes energéticas (sorgo ou farelo de trigo) associadas ao milho para bezerros lactentes.

Palavras-chave: Bovinos. Desempenho. Forragem. Milho. Nitrogênio.

\section{Introduction}

In the scenario of constant search for intensification of beef cattle production systems, the pre-weaning stage has received special attention. During this phase, calves have the potential for greater weight gains. Weaning heavier animals is interesting, as it allows males to be slaughtered and heifers to mate before sixteen months of age (PAULINO et al., 2012).

However, some physiological changes that occur in calves, in dams, and in the forage may compromise the production efficiency of the preweaning phase. The first months of life of a calf are characterized by changes in its digestive tract, effectively making it a ruminant animal. The nutritional requirements of a calf are increased with its growth, which coincides with the period of decline in milk production of dams and also in forage quality. In a production system in which the cattle breeding season takes place during the rainy season, the longest calf growth stage occurs in the rainy-dry transition. These factors may limit animal performance, since the availability of nutrients from milk and forage may not be sufficient to meet the requirements of the animal (PORTO et al., 2009).

To ensure continued growth to animals and to overcome such problems, the practice of supplementation is then necessary. The use of creep feeding has contributed to the resolution of these problems, providing higher weaning weights to these animals (PORTO et al., 2009; LOPES et al., 2013). The feed used during this phase must have a good nutritional value and be palatable to stimulate consumption by the animals, given that intake is directly related to the animal performance and to the supplementation cost.

The practice of supplementing grazing cattle is responsible for an increase in production costs. Therefore, nutritionists have sought alternative feeds that do not compromise animal performance and that can reduce the supplementation cost. The sorghum and the wheat bran are feedstuffs that have been replacing corn in some supplementation programs (PEREIRA et al., 2007; CARVALHO et 
al., 2009; PORTO et al., 2009) due to their similar chemical composition, but little is known about the use and acceptance of these ingredients by suckling calves.

The objective of this study was to evaluate the effect of different energy sources (corn, sorghum, and wheat bran) on performance, intake, apparent digestibility of dietary components, and utilization efficiency of nitrogen compounds by beef calves subjected to creep feeding.

\section{Material and Methods}

All procedures involving animals were approved by the Brazilian Committee for Animal Care and Experimentation, under no. 29/2014.

The experiment was carried out at Universidade Federal de Viçosa, located in Viçosa, MG, Brazil, between March and June 2013. The experimental area is located in a mountainous region at an altitude of $670 \mathrm{~m}$; the average precipitation during the experimental period was $107 \mathrm{~mm} /$ month. Animals underwent 15 days of adaptation to the diet and to the experimental area and 112 days (four periods of 28 days) for experimental evaluation.

Thirty-four Nellore beef calves in the suckling phase with an average age of 120 days and an average initial body weight of $108 \pm 3.9 \mathrm{~kg}$ and their respective dams with an average body weight of $452 \pm 15.9 \mathrm{~kg}$ were used in this experiment. All animals were subjected to the control of ecto and endoparasites at the beginning of the experiment.

Cow-calf pairs were placed in a 20-ha plot covered with Urochloa decumbens pastures. Individual feeders were available for each group of calves ( $0.5 \mathrm{~m}$ per calf), and cows had no access to them. Calves were fed once daily at 11h00. Cows received a mineral mixture ad libitum.

To minimize possible effects of the plots on the experimental treatments, animals were rotated across the four pastures every seven days, so each group stayed in each plot for the same amount of time.

The supplements utilized were formulated to contain $20 \%$ crude protein (CP), including soybean meal, a mineral mixture, molasses and the following energy sources: corn (C), corn + sorghum $(\mathrm{C}+\mathrm{S})$, and corn + sorghum + wheat bran $(\mathrm{C}+\mathrm{S}+\mathrm{WB})$. Animals on the control treatment (MM) received the mineral mixture ad libitum (Table 1). At the beginning of the experiment and every 28 days thereafter, animals were weighed without fasting and always in the morning to adjust the amount of supplement to be provided to each group (at a rate of $0.5 \%$ of the body weight (BW) of the calves. For performance evaluation, animals were weighed at the beginning and end of the experiment after $14 \mathrm{~h}$ of fasting.

Table 1. Composition of supplements (\%) on an as-is basis.

\begin{tabular}{lcccc}
\hline \multirow{2}{*}{ Ingredient (\%) } & \multicolumn{4}{c}{ Supplement $^{2}$} \\
\cline { 2 - 5 } & $\mathrm{MM}$ & $\mathrm{C}$ & $\mathrm{C}+\mathrm{S}$ & $\mathrm{C}+\mathrm{S}+\mathrm{WB}$ \\
\hline Mineral mixture $^{1}$ & 100 & 6 & 6 & 6 \\
Ground corn grain & --- & 62 & 31 & 13 \\
Ground sorghum grain & --- & --- & 31 & 13 \\
Wheat bran & --- & --- & --- & 45 \\
Soybean meal & --- & 29 & 29 & 20 \\
Molasses & --- & 3 & 3 & 3 \\
\hline
\end{tabular}

${ }^{1}$ Centesimal composition: dicalcium phosphate, 50.0; sodium chloride, 47,8; zinc sulfate, 1.5; copper sulfate, 0.05; cobalt sulfate, 0.05 ; potassium iodate, 0.05 ; sodium selenite, 0.05 ; manganese sulfate, 0.5 . ${ }^{2} \mathrm{MM}$ - mineral mixture; $\mathrm{C}$ - corn; $\mathrm{C}+\mathrm{S}$ corn and sorghum; $\mathrm{C}+\mathrm{S}+\mathrm{WB}$ - corn, sorghum, and wheat bran.

Forage samples were collected on the 14th day of each experimental period to evaluate forage mass $\left(\mathrm{DM}, \mathrm{kg} \mathrm{ha}^{-1}\right.$ ) and potentially digestible forage mass $\left(\mathrm{pdDM}, \mathrm{kg} \mathrm{ha}^{-1}\right)$. In each plot, four forage samples were randomly selected using a metal square $(0.5$ $\times 0.5 \mathrm{~m})$ and by making a cut at approximately 1 $\mathrm{cm}$ above the ground. The pdDM was estimated according to the equation proposed by Paulino et al. (2006), as follows: 


$$
\mathrm{pdDM}=0.98(100-\mathrm{NDF})+(\mathrm{NDF}-\mathrm{iNDF})
$$

where NDF = neutral detergent fiber; and iNDF $=$ indigestible neutral detergent fiber.

Samples for the qualitative assessment of forage consumed by the animals were obtained every 14 days by the hand-plucking method. All samples were dried $\left(55^{\circ} \mathrm{C}\right.$ for $\left.72 \mathrm{~h}\right)$ and ground (1 and 2 $\mathrm{mm})$.

Fifty-five days after the beginning of the experiment, a 9-day trial to evaluate the intake and digestion of the calves was undertaken. It took 6 days for the adaptation of animals to titanium dioxide $\left(\mathrm{TiO}_{2}\right)$ (TITGEMEYER et al., 2001) and to chromium oxide $\left(\mathrm{Cr}_{2} \mathrm{O}_{3}\right)$ (SAMPAIO et al., 2011) and 3 days for feces collection at different times: 15h00, 10h00, and 07h00. Chromium oxide, used to estimate fecal excretion, was packaged in paper cartridges in the amount of $10 \mathrm{~g}$ per animal day ${ }^{-1}$ for calves and was directly introduced into the esophagus by using an applicator always around 09h00, while titanium dioxide was used to estimate supplement individual intake, mixed with the supplement distributed to the calves in an amount equal to $10 \mathrm{~g} \mathrm{~kg}^{-1}$ of supplement provided. The iNDF was used as a marker to estimate the dry matter intake.

Fecal samples (collected from the rectum or immediately after defecation of the animals in quantities of approximately $200 \mathrm{~g}$ every day) were dried at $55{ }^{\circ} \mathrm{C}$ for $72 \mathrm{~h}$, ground to pass through a 1 -mm screen, and sub-sampled proportionally into a composite sample.

To evaluate the microbial protein production of calves, spot urine samples $(10 \mathrm{~mL})$ were collected from spontaneous urination $4 \mathrm{~h}$ after supplement supply (on the 63th experimental day). Urine samples were diluted in $40 \mathrm{~mL} \mathrm{H}_{2} \mathrm{SO}_{4}$ $(0.036 \mathrm{~N})$ and frozen at $-20{ }^{\circ} \mathrm{C}$ for subsequent laboratory analysis to determine creatinine, urea, uric acid, allantoin, and nitrogen levels. After urine collection, blood samples were collected by jugular venipuncture, using vacuum tubes with separator gel (BD Vacutainer ${ }^{\circledR}$ SSTII Advance), and centrifuged at $2700 \mathrm{x}$ for $15 \mathrm{~min}$; the serum was then frozen at $-20{ }^{\circ} \mathrm{C}$ for subsequent analysis of urea level.

Milk dry matter intake (MDM) by calves was estimated as the average of the estimates obtained on days 40,70, and 100 of the experimental period. The procedures were performed similarly to the description by Valente et al. (2012). Crude protein, fat, lactose, and total solids were evaluated in the sampled milk. Analyses were performed using MilkoScan ${ }^{\mathrm{TM}}$ Minor equipment, by near infrared spectrophotometry.

Samples of forage, supplements, and feces were evaluated for dry matter (DM), organic matter $(\mathrm{OM})$, crude protein $(\mathrm{CP})$, ether extract (EE), neutral detergent fiber corrected for ash and protein (NDFap), and indigestible neutral detergent fiber (iNDF). Feces samples were also analyzed for chromium and titanium concentrations following the techniques described by Detmann et al. (2012). Non-fibrous carbohydrates of the supplements were estimated according to recommendations of Detmann and Valadares Filho (2010), using the equation below:

$$
\mathrm{NFC}=100-(\% \mathrm{CP}+\% \mathrm{NDFap}+\% \mathrm{EE}+\% \text { ash })
$$

The chemical composition of supplement, forage, and milk consumed by the animals is shown in Table 2.

Fecal excretion was estimated by considering the ratio between quantity of marker supplied and its concentration in the feces. The individual supplement intake was estimated by the following equation proposed by Ferreira et al. (2009):

$$
\mathrm{ISI}=\mathrm{FE} \times \mathrm{MFe} / \mathrm{MS}
$$

where ISI = individual supplement intake $(\mathrm{kg}$ day $\left.^{-1}\right) ; \mathrm{FE}=$ fecal excretion $\left(\mathrm{kg}\right.$ day $\left.^{-1}\right) ; \mathrm{MFe}=$ marker concentration in the feces $\left(\mathrm{g} \mathrm{kg}^{-1}\right)$; $\mathrm{MS}=$ marker concentration in the supplement $\left(\mathrm{g} \mathrm{kg}^{-1}\right)$. 
Table 2. Chemical composition of supplements, forage, and milk consumed by animals.

\begin{tabular}{|c|c|c|c|c|c|}
\hline \multirow{2}{*}{ Item } & \multicolumn{3}{|c|}{ Supplement $^{4}$} & \multirow{2}{*}{ U. Decumbens ${ }^{5}$} & \multirow{2}{*}{ U. Decumbens } \\
\hline & $\mathrm{C}$ & $\mathrm{C}+\mathrm{S}$ & $\mathrm{C}+\mathrm{S}+\mathrm{WB}$ & & \\
\hline Dry matter ${ }^{2}$ & 91.47 & 92.40 & 91.45 & $22.65 \pm 0.67$ & $25.32 \pm 2.23$ \\
\hline Organic matter ${ }^{3}$ & 91.39 & 91.89 & 91.27 & $91.55 \pm 0.11$ & $91.19 \pm 0.46$ \\
\hline Crude protein ${ }^{3}$ & 19.48 & 20.15 & 18.67 & $12.61 \pm 0.10$ & $10.55 \pm 0.63$ \\
\hline Ether extract ${ }^{3}$ & 3.18 & 2.11 & 2.72 & $1.44 \pm 0.13$ & $1.06 \pm 0.08$ \\
\hline NDFap ${ }^{1,3}$ & 14.49 & 14.40 & 20.93 & $62.08 \pm 0.93$ & $65.99 \pm 0.49$ \\
\hline $\mathrm{NFC}^{1,3}$ & 54.24 & 55.23 & 48.95 & $15.42 \pm 0.58$ & $13.59 \pm 0.93$ \\
\hline \multirow[t]{3}{*}{$\mathrm{iNDF}^{1,3}$} & 1.09 & 1.15 & 5.52 & $20.21 \pm 1.03$ & $27.24 \pm 1.45$ \\
\hline & \multicolumn{5}{|c|}{ Milk component $^{7}$} \\
\hline & Production & Protein & Fat & Lactose & Total solids \\
\hline Mean & $6.07 \pm 0.26$ & $3.44 \pm 0.06$ & $4.75 \pm 0.13$ & $4.33 \pm 0.05$ & $13.64 \pm 0.17$ \\
\hline
\end{tabular}

${ }^{1} \mathrm{NDF}$ ap - neutral detergent fiber correct for ash and protein; NFC - non-fibrous carbohydrates; iNDF - indigestible neutral detergent fiber. ${ }^{2}$ Percentage of natural matter. ${ }^{3}$ Percentage of dry matter. ${ }^{4} \mathrm{C}$ - corn; $\mathrm{C}+\mathrm{S}$ - corn and sorghum; $\mathrm{C}+\mathrm{S}+\mathrm{WB}-\mathrm{corn}$, sorghum, and wheat bran. ${ }^{5}$ Mean \pm standard error of the mean (samples from hand-plucking obtained during the entire experimental period). ${ }^{6}$ Mean \pm standard error of the mean (samples from hand-plucking obtained during evaluation of nutritional traits). ${ }^{7} \mathrm{Mean} \pm$ standard error of the mean of milk components, as is, with production in $\mathrm{kg}$ corrected for $4 \%$ fat.

The voluntary intake of forage dry matter was estimated by using iNDF as an internal marker, by adjusting the equation proposed by Detmann et al. (2001):

$$
\operatorname{VIDM}\left(\mathrm{kg} \mathrm{day}^{-1}\right)=((\mathrm{FE} \times \mathrm{MCFe})-\mathrm{MS}) / \mathrm{MCFo}
$$

where VIDM = voluntary intake of forage dry matter; $\mathrm{FE}=$ fecal excretion $\left(\mathrm{kg}\right.$ day $\left.^{-1}\right) ; \mathrm{MCFe}=$ marker concentration in the feces $\left(\mathrm{kg} \mathrm{kg}^{-1}\right)$; $\mathrm{MS}=$ intake of internal marker from the supplement $(\mathrm{kg}$ day $\left.^{-1}\right)$; and $\mathrm{MCFo}=$ marker concentration in the forage $\left(\mathrm{kg} \mathrm{kg}^{-1}\right)$.

For quantification of creatinine, uric acid, and urea, an automated device for biochemistry (Mindray mark, model BS200E) and Bioclin kits were used. Creatinine was quantified using the colorimetric kinetic method. Evaluation of uric acid was carried out using the enzymatic colorimetric method. Urea was quantified by the fixed-time kinetic method. Analyses were performed by the allantoin colorimetric method, as described by Chen and Gomes (1992).

Daily urine volume was estimated using the ratio between the daily excretion of creatinine
(CE), adopting the equation proposed by Silva et al. (2012), and its concentration in the spot samples as a reference:

$$
\mathrm{CE}\left(\mathrm{g} \mathrm{day}^{-1}\right)=0.0345 \times \mathrm{FBW}^{0.9491}
$$

where FBW = fasted body weight, obtained by the equation $0.96 \times \mathrm{BW}(\mathrm{NRC}, 1996)$.

Total excretion of purine derivatives were estimated by summing the amounts of allantoin and uric acid excreted in the urine, expressed in mmol day $^{-1}$. The absorbed purines (Y, mmol day ${ }^{-1}$ ) were calculated from the excretion of purine derivatives $\left(\mathrm{X}, \mathrm{mmol} \mathrm{day}^{-1}\right)$, by the following equation:

$$
\mathrm{Y}=\left(\mathrm{X}-0.301 \times \mathrm{BW}^{0.75}\right) / 0.80
$$

where $0.301 * \mathrm{BW}^{0.75}=$ endogenous contribution for the excretion of purines; and $0.80=$ recovery of absorbed purines as purine derivatives (BARBOSA et al., 2011).

The ruminal synthesis of nitrogen compounds (Nmic; g Nmic day ${ }^{-1}$ ) was calculated as a function of absorbed purines (X, mmol day ${ }^{-1}$ ), by using the equation described by Barbosa et al. (2011):

$$
\mathrm{Nmic}=70 \mathrm{X} /(0.93 \times 0.137 \times 1000)
$$


where $70=$ microbial purines $\mathrm{N}$ content $(\mathrm{mg} \mathrm{N}$ $\left.\mathrm{mol}^{-1}\right) ; 0.93=$ digestibility of bacterial purines; and $0.137=$ purine $\mathrm{N}$ :total bacterial $\mathrm{N}$ ratio.

The experiment was conducted as a randomized block design with four treatments and two blocks consisting of the gender of the animals. Each animal was considered an experimental unit. Treatments $\mathrm{MM}$ and $\mathrm{C}$ had nine replicates, while treatments $\mathrm{C}+\mathrm{S}$ and $\mathrm{C}+\mathrm{S}+\mathrm{WB}$ had eight replicates. PROC MIXED procedure of SAS software (Statistical Analysis System, version 9.4) was applied for all statistical analyses. For all statistical procedures, $\alpha$ $=0.05$. Data were subjected to analysis of variance and the initial body weight was used as a covariate when significant. The contrast between the treatment means was performed through Fisher's least significant difference test.

\section{Results and Discussion}

When cattle are raised on pasture, forage is the main source of energy and nutrients for them, and so it is extremely important that it be in sufficient quantity and quality to meet the nutritional requirements of animals. The concept of pdDM encompasses the quality of the forage available to the animal, which must be provided in the amount of 40 to $50 \mathrm{~g} \mathrm{~kg}^{-1}$ body weight per day (PAULINO et al., 2004). During the experimental evaluation, the pdDM availability was $28.4 \mathrm{~g} \mathrm{~kg}^{-1}$ body weight.

The average CP content of the forage during the experimental period was $12.6 \%$ (Table 2 ), which is higher than the $7 \%$ recommended by Sampaio et al. (2009) as the minimum concentration required for proper use of the neutral detergent fiber, the main source of energy for cattle in a grazing system.

Although the forage quality was not limiting, the low availability of pdDM compromised the animal performance. Supplemented animals showed an average gain of $631 \mathrm{~g} \mathrm{day}^{-1}, 120 \mathrm{~g}$ more than the unsupplemented animals (Table 3 ). The highest daily gain corresponded to an increase of $13.2 \mathrm{~kg}$ in the final weight of the animals that were supplemented. There was no difference in ADG and FBW between the different energy sources $(\mathrm{P}>0.05)$.

Table 3. Means, standard error of the mean (SEM), and indicators of significance for average daily gain and final body weight according to the different treatments.

\begin{tabular}{|c|c|c|c|c|c|c|}
\hline \multirow{2}{*}{ Item } & \multicolumn{4}{|c|}{ Supplement $^{1,2}$} & \multirow{2}{*}{ SEM } & \multirow{2}{*}{$P$-value } \\
\hline & MM & $\mathrm{C}$ & $\mathrm{C}+\mathrm{S}$ & $\mathrm{C}+\mathrm{S}+\mathrm{WB}$ & & \\
\hline Average daily gain ${ }^{3}$ & $0.511 b$ & $0.617 \mathrm{a}$ & $0.655 \mathrm{a}$ & $0.621 \mathrm{a}$ & 0.0348 & 0.042 \\
\hline Final body weight ${ }^{3}$ & $158.0 \mathrm{~b}$ & $169.7 \mathrm{a}$ & $173.9 \mathrm{a}$ & $170.1 \mathrm{a}$ & 3.83 & 0.042 \\
\hline
\end{tabular}

${ }^{1} \mathrm{MM}$ - mineral mixture; $\mathrm{C}$ - corn; $\mathrm{C}+\mathrm{S}$ - corn and sorghum; $\mathrm{C}+\mathrm{S}+\mathrm{WB}$ - corn, sorghum, and wheat bran. ${ }^{2} \mathrm{Means}$ in the row followed by different letters are different $(\mathrm{P}<0.05) .{ }^{3}$ in $\mathrm{kg}$.

Supplemented animals showed higher $(\mathrm{P}<0.05)$ intakes of DM, OM, CP, NFC, and dOM (Table 4). There were no differences in the intakes of MDM and FDM. Crude protein intake was higher $(\mathrm{P}<0.05)$ in supplemented animals as compared with the animals on the MM treatment. Supplemented animals showed a higher protein concentration because of the composition of the supplement. Among the supplemented treatments, $\mathrm{C}+\mathrm{S}$ provided the highest $\mathrm{CP}$ intake $(\mathrm{P}<0.05)$.

The supplements were formulated to contain $20 \% \mathrm{CP}$, on a dry matter basis; however, when laboratory analyses were performed, it was found that the $\mathrm{C}+\mathrm{S}$ treatment had $20.15 \% \mathrm{CP}$, while treatments $\mathrm{C}$ and $\mathrm{C}+\mathrm{S}+\mathrm{WB}$ showed $19.48 \%$ and $18.67 \% \mathrm{CP}$, respectively, which explains the higher intake of $\mathrm{CP}$ by the animals fed the $\mathrm{C}+\mathrm{S}$ treatment. 
Table 4. Means, standard error of the mean (SEM), and indicators of significance for intakes of nutrients according to the different treatments.

\begin{tabular}{|c|c|c|c|c|c|c|}
\hline \multirow{2}{*}{ Item } & \multicolumn{4}{|c|}{ Supplement ${ }^{2,3}$} & \multirow{2}{*}{ SEM } & \multirow{2}{*}{$P$-value } \\
\hline & MM & $\mathrm{C}$ & $\mathrm{C}+\mathrm{S}$ & $\mathrm{C}+\mathrm{S}+\mathrm{WB}$ & & \\
\hline \multicolumn{7}{|c|}{$\mathrm{kg} \mathrm{day}^{-1}$} \\
\hline Dry matter & $1.98 \mathrm{~b}$ & $3.27 \mathrm{a}$ & $3.10 \mathrm{a}$ & $2.94 \mathrm{a}$ & 0.281 & 0.004 \\
\hline Forage dry matter & 1.36 & 1.89 & 1.61 & 1.89 & 0.269 & 0.112 \\
\hline Milk dry matter & 0.64 & 0.64 & 0.82 & 0.67 & 0.107 & 0.430 \\
\hline Supplement dry matter & - & 0.69 & 0.68 & 0.40 & 0.119 & 0.163 \\
\hline Organic matter & $1.83 \mathrm{~b}$ & $2.96 \mathrm{a}$ & $2.86 \mathrm{a}$ & $2.72 \mathrm{a}$ & 0.200 & $<0.001$ \\
\hline Crude protein & $0.278 \mathrm{c}$ & $0.468 b$ & $0.553 \mathrm{a}$ & $0.451 \mathrm{~b}$ & 0.0268 & $<0.001$ \\
\hline Ether extract & 0.242 & 0.290 & 0.328 & 0.267 & 0.0376 & 0.404 \\
\hline NDFap $^{1}$ & $0.92 b$ & $1.35 \mathrm{a}$ & $1.14 \mathrm{ab}$ & $1.31 \mathrm{a}$ & 0.179 & 0.049 \\
\hline Non-fibrous carbohydrates & $0.20 \mathrm{~d}$ & $0.67 \mathrm{a}$ & $0.55 \mathrm{~b}$ & $0.45 \mathrm{c}$ & 0.040 & $<0.001$ \\
\hline $\mathrm{iNDF}^{1}$ & 0.45 & 0.54 & 0.43 & 0.44 & 0.076 & 0.259 \\
\hline $\mathrm{dNDF}^{1}$ & $0.48 b$ & $0.72 \mathrm{a}$ & $0.71 \mathrm{a}$ & $0.85 \mathrm{a}$ & 0.090 & 0.001 \\
\hline Digestible organic matter & $1.10 \mathrm{~b}$ & $1.87 \mathrm{a}$ & $2.09 \mathrm{a}$ & $1.92 \mathrm{a}$ & 0.103 & $<0.001$ \\
\hline \multicolumn{7}{|c|}{$\mathrm{g} \mathrm{kg}^{-1}$ of BW } \\
\hline Dry matter & $13.2 \mathrm{~b}$ & $20.9 \mathrm{a}$ & $21.2 \mathrm{a}$ & $22.3 \mathrm{a}$ & 2.14 & 0.007 \\
\hline Forage dry matter & 9.2 & 12.1 & 11.1 & 14.4 & 2.03 & 0.081 \\
\hline Organic matter & $12.3 b$ & $19.0 \mathrm{a}$ & $19.8 \mathrm{a}$ & $20.6 a$ & 1.79 & 0.001 \\
\hline NDFap $^{1}$ & 6.3 & 8.6 & 7.9 & 10.0 & 1.37 & 0.054 \\
\hline $\mathrm{iNDF}^{1}$ & 3.0 & 3.5 & 2.9 & 3.3 & 0.55 & 0.663 \\
\hline
\end{tabular}

${ }^{1}$ Neutral detergent fiber corrected for ash and protein. Indigestible neutral detergent fiber. Digestible neutral detergent fiber. ${ }^{2} \mathrm{MM}$ - mineral mixture; $\mathrm{C}$ - corn; $\mathrm{C}+\mathrm{S}$ - corn and sorghum; $\mathrm{C}+\mathrm{S}+\mathrm{WB}$ - corn, sorghum, and wheat bran. ${ }^{3}$ Means in the row followed by different letters are different $(\mathrm{P}<0.05)$.

Non-fibrous carbohydrates intake showed a decreasing trend, in the following order: $\mathrm{C}, \mathrm{C}+\mathrm{S}$, $\mathrm{C}+\mathrm{S}+\mathrm{WB}$, and $\mathrm{MM}$. This decreasing response can be explained by the fact that the concentration of corn in the diet decreased with the addition of other feedstuffs. Among the feedstuffs utilized, corn had the highest concentration of NFC.

Supplementing grazing cattle is a practice aimed at providing additional nutrients and overcoming the deficiencies of the productive system. In general, supplementation has an impact on forage intake and animal performance. However, in some cases, the expected results are not always observed, due to the interactions between forage and supplements, known as the association effect between foods (PAULINO et al., 2004).

Forage dry matter intake showed no significant differences $(\mathrm{P}>0.05)$; however, a numerical increase of $440 \mathrm{~g} \mathrm{day}^{-1}$ in this variable was observed when animals were supplemented. This increase can be explained by improvements in ruminal conditions caused by supplementation and also explains the higher $(\mathrm{P}<0.05)$ intakes of NDFap and dNDF by supplemented animals. Treatments did not influence $(\mathrm{P}>0.05)$ the intakes of MDM, SDM, EE, and iNDF.

Supplement dry matter intake was not affected by the different treatments, although it was noted that animals from treatment $\mathrm{C}+\mathrm{S}+\mathrm{WB}$ consumed approximately $300 \mathrm{~g}$ day $^{-1}$ unless other treatments, $\mathrm{C}$ and $\mathrm{C}+\mathrm{S}$. Wheat bran has a high water-retention capacity, an adjuvant effect, which may have caused discomfort in the mouth of the animals ingesting this feedstuff and limited supplement intake. However, despite the lower intake, the animal performance was not affected. 
Evaluating the effect of supplementing calves in creep feeding, Porto et al. (2009) also observed a reduction of over $300 \mathrm{~g}$ day $^{-1}$ in supplement intake in animals fed wheat bran; however, their performance also was not affected.

When concentrate supplementation is provided, in most cases, improvements are observed in the digestibility of dietary components because the substrates required for rumen microorganisms and fibrolytic bacteria to increase in number and in fiber degradability are provided (DOYLE et al., 2005).

Treatments $\mathrm{C}+\mathrm{S}$ and $\mathrm{C}+\mathrm{S}+\mathrm{WB}$ increased $(\mathrm{P}<0.05)$ the apparent digestibility of OM, CP, and NDFap (Table 5), probably because of the improved ruminal conditions. The same response was not observed in treatment C. Corn is a food rich in prolamines and water-insoluble proteins, and has low ruminal digestibility. The higher proportion of prolamines in the corn may be one of the reasons why treatment $\mathrm{C}$ did not stimulate the apparent digestibility of CP.

Table 5. Means, standard error of the mean (SEM), and indicators of significance for digestibility of nutrients according to the different treatments

\begin{tabular}{|c|c|c|c|c|c|c|}
\hline \multirow{2}{*}{ Item } & \multicolumn{4}{|c|}{ Supplement ${ }^{5,6}$} & \multirow{2}{*}{ SEM } & \multirow{2}{*}{$P$-value } \\
\hline & MM & $\mathrm{C}$ & $\mathrm{C}+\mathrm{S}$ & $\mathrm{C}+\mathrm{S}+\mathrm{WB}$ & & \\
\hline Organic matter ${ }^{2}$ & $0.608 b$ & $0.640 \mathrm{~b}$ & $0.735 \mathrm{a}$ & $0.716 \mathrm{a}$ & 0.0316 & $<0.001$ \\
\hline Crude protein ${ }^{2}$ & $0.632 b c$ & $0.610 \mathrm{c}$ & $0.754 \mathrm{a}$ & $0.704 \mathrm{ab}$ & 0.0399 & 0.006 \\
\hline Ether extract ${ }^{2}$ & 0.854 & 0.821 & 0.886 & 0.843 & 0.0300 & 0.237 \\
\hline $\mathrm{NDFap}^{1,2}$ & $0.521 b$ & $0.542 b$ & $0.633 \mathrm{a}$ & $0.663 a$ & 0.0164 & $<0.001$ \\
\hline $\mathrm{NFC}^{1,2}$ & $0.232 b$ & $0.672 \mathrm{a}$ & $0.692 \mathrm{a}$ & $0.645 \mathrm{a}$ & 0.0317 & $<0.001$ \\
\hline $\mathrm{dOM}^{1,3}$ & 565 & 601 & 700 & 684 & 40.2 & 0.052 \\
\hline $\mathrm{CP}: \mathrm{dOM}^{1,4}$ & $251 \mathrm{a}$ & $250 \mathrm{a}$ & $264 \mathrm{a}$ & $234 b$ & 6.0 & 0.003 \\
\hline
\end{tabular}

${ }^{1}$ Neutral detergent fiber corrected for ash and protein. Non-fibrous carbohydrates. Digestible organic matter. Protein: dietary energy. ${ }^{2} \mathrm{~g} \mathrm{~g}^{-1} .{ }^{3} \mathrm{~g} \mathrm{~kg} \mathrm{DM}^{-1} .{ }^{4} \mathrm{~g} \mathrm{CP} / \mathrm{kg} \mathrm{dOM} .{ }^{5} \mathrm{MM}$ - mineral mixture; $\mathrm{C}$ - corn; $\mathrm{C}+\mathrm{S}$ - corn and sorghum; $\mathrm{C}+\mathrm{S}+\mathrm{WB}$ - corn, sorghum, and wheat bran. ${ }^{6}$ Means in the row followed by different letters are different $(\mathrm{P}<0.05)$.

Because the $\mathrm{CP}$ of treatment $\mathrm{C}$ showed lower digestibility than the other supplemented treatments, there may have been a lack of nitrogen compounds in the rumen of animals from this treatment, and this deficiency resulted in lower $(\mathrm{P}<0.05)$ apparent digestibility of the fiber. The concentrate supplementation improved $(\mathrm{P}<0.05)$ the apparent digestibility of NFC. There was no effect $(\mathrm{P}>0.05)$ of treatments on apparent digestibility of EE and dOM.

The CP:dOM ratio works as indicative of the protein:dietary energy ratio and helps us to understand the metabolic effects of protein on intake, since this ratio acts as a regulating parameter in the voluntary intake of ruminants.
Detmann et al. (2014) stated that both excess protein and excess energy can compromise the voluntary forage intake. Excess energy can limit the intake due to the increased production of heat, and excess protein may also limit the intake due to the increased heat generated by excessive use of the urea cycle or excess ammonia in the blood, causing discomfort to the animal. These authors observed that the forage intake was maximized when the CP:dOM ratio was close to $288 \mathrm{~g} \mathrm{CP} / \mathrm{kg}$ $\mathrm{dOM}$ in tropical conditions. In the present study, the CP:dOM ratio found was lower than the 249 $\mathrm{g} \mathrm{CP} / \mathrm{kg}$ dOM reported by the abovementioned author, on average, and did not affect forage intake. 
Microbial growth is affected by the availability of nutrients required by rumen microorganisms such as carbohydrates, ammonia, peptides, amino acids, sulfur, and branched-chain fatty acids (VAN SOEST, 1994). Therefore, when cattle are supplemented, they are expected to show a greater microbial production, since the microorganisms have a higher concentration of nutrients. However, this behavior is not always observed, which may be related to a lack of synchronization between energy and nitrogen compounds available in the rumen. In this study, the animals on treatments $\mathrm{C}+\mathrm{S}$ and $\mathrm{C}+\mathrm{S}+\mathrm{WB}$ showed lower $(\mathrm{P}<0.05)$ microbial protein production compared with those on the other treatments, MM and C (Table 6).

Table 6. Means, standard error of the mean (SEM), and indicators of significance for ruminal synthesis of nitrogen compounds (Nmic), serum urea nitrogen (SUN), urine urea nitrogen (UUN), nitrogen intake (NI), nitrogen in urine (NU), nitrogen in feces (NF), nitrogen balance (NB), and nitrogen utilization efficiency (NUE) according to the different treatments.

\begin{tabular}{|c|c|c|c|c|c|c|}
\hline \multirow{2}{*}{ Item } & \multicolumn{4}{|c|}{ Supplement $^{5,6}$} & \multirow{2}{*}{ SEM } & \multirow{2}{*}{$P$-value } \\
\hline & MM & $\mathrm{C}$ & $\mathrm{C}+\mathrm{S}$ & $\mathrm{C}+\mathrm{S}+\mathrm{WB}$ & & \\
\hline $\mathrm{Nmic}^{2}$ & $31.56 \mathrm{a}$ & $30.96 a$ & $25.74 b$ & $18.22 \mathrm{c}$ & 1.612 & $<0.001$ \\
\hline $\mathrm{SUN}^{4}$ & 11.56 & 11.96 & 11.78 & 11.02 & 0.783 & 0.848 \\
\hline $\mathrm{UUN}^{2}$ & 18.60 & 23.57 & 23.17 & 18.82 & 1.718 & 0.076 \\
\hline $\mathrm{NI}^{2}$ & $46.45 \mathrm{c}$ & $74.97 b$ & $88.48 \mathrm{a}$ & $72.12 b$ & 4.379 & $<0.001$ \\
\hline $\mathrm{NU}^{2}$ & 27.10 & 32.14 & 32.03 & 26.31 & 2.285 & 0.167 \\
\hline $\mathrm{NF}^{2}$ & $15.20 \mathrm{~b}$ & $29.13 \mathrm{a}$ & $21.32 b$ & $21.50 \mathrm{~b}$ & 2.819 & 0.011 \\
\hline $\mathrm{NB}^{1,2}$ & $4.61 \mathrm{~b}$ & $13.86 \mathrm{ab}$ & $35.29 \mathrm{a}$ & $24.48 \mathrm{a}$ & 3.887 & $<0.001$ \\
\hline $\mathrm{NUE}^{1,3}$ & $0.078 \mathrm{~b}$ & $0.177 \mathrm{~b}$ & $0.398 \mathrm{a}$ & $0.344 \mathrm{a}$ & 0.0470 & $<0.001$ \\
\hline
\end{tabular}

${ }^{1} \mathrm{NB}\left(\mathrm{NI}\right.$ - NU - NF); NUE (NB/NI). ${ }^{2} \mathrm{~g} \mathrm{day}{ }^{-1} \cdot{ }^{3} \mathrm{~g} \mathrm{~g}^{-1} .{ }^{4} \mathrm{mg} \mathrm{dL}{ }^{-1} .{ }^{5} \mathrm{MM}$ - mineral mixture; $\mathrm{C}$ - corn; $\mathrm{C}+\mathrm{S}$ - corn and sorghum; $\mathrm{C}+\mathrm{S}+\mathrm{WB}$ - corn, sorghum, and wheat bran. ${ }^{6}$ Means in the row followed by different letters are different $(\mathrm{P}<0.05)$.

The serum urea nitrogen (SUN) level acts as a sensitive and immediate indicator of the protein metabolism in animals (GONZALES; SCHEFFER, 2002). This variable was not affected by the concentrate supplementation $(\mathrm{P}>0.05)$, and neither $(\mathrm{P}>0.05)$ was the urine urea nitrogen excretion (UUN).

There was no difference $(\mathrm{P}>0.05)$ in nitrogen urinary excretion (NU) between treatments. Supplemented animals consumed more nitrogen (NI, $\mathrm{P}<0.05$ ) compared with those without supplementation. The lack of a significant effect on nitrogen excretions in urine (UUN and NU) associated with the higher NI by the supplemented animals indicates better use of the nitrogen consumed by these animals. The higher $(\mathrm{P}<0.05)$ nitrogen balance (NB) of the supplemented animals confirms this hypothesis. The lower apparent digestibility of $\mathrm{CP}$ of treatment $\mathrm{C}$ explains the higher $\mathrm{NF}(\mathrm{P}<0.05)$ of these animals.

The nitrogen utilization efficiency (NUE) works as a measure to assess the efficiency with which animals utilize nitrogen. Animals on treatments $\mathrm{C}+\mathrm{S}$ and $\mathrm{C}+\mathrm{S}+\mathrm{WB}$ were more efficient $(\mathrm{P}<0.05)$ in utilizing nitrogen as compared with the animals from treatments MM and C.

Concentrate supplementation improved animal performance. The use of other energy sources (sorghum or wheat bran) associated with corn for suckling calves is thus recommended. 


\section{References}

BARBOSA, A. M.; VALADARES, R. F. D.; VALADARES FILHO, S. C.; PINA, D. S.; DETMANN, E.; LEÃO, M. I. Endogenous fraction and urinary recovery of purine derivatives obtained by different methods in Nellore cattle. Journal of Animal Science, Champaign, v. 89, n. 2, p. 510-519, 2011.

CARVALHO, D. M. G.; ZERVOUDAKIS, J. T.; CABAL, L. S.; PAULA, N. F.; MORAES, E. H. B. K.; OLIVEIRA, A. A.; KOSCHECK, J. F. W. Fontes de energia em suplementos múltiplos para recria de bovinos em pastejo no período da seca: desempenho e análise econômica. Revista Brasileira de Saúde e Produção Animal, Salvador, v. 10, n. 3, p. 760-773, 2009.

CHEN, X. B.; GOMES, M. J. Estimation of microbial protein supply to sheep and cattle based on urinary excretion of purine derivatives - an overview of technical details. Ocasional Publication. Buchsburnd Aberdeen, Buchsburnd Aberdeen: Rowett Research Institute, 1992. $21 \mathrm{p}$.

DETMANN, E.; PAULINO, M. F.; ZERVOUDAKIS, J. T.; VALADARES FILHO, S. C.; EUCLYDES, R. F.; LANA, R. P.; QUEIROZ, D. S. Cromo e indicadores internos na estimação do consumo de novilhos mestiços, suplementados, a pasto. Revista Brasileira de Zootecnia, Viçosa, MG, v. 30, n. 5, p. 1600-1609, 2001.

DETMANN, E.; SOUZA, M. A.; VALADARES FILHO, S. C. Métodos para análise de alimentos - INCT - Ciência Animal. Visconde do Rio Branco, MG: Suprema, 2012. $214 \mathrm{p}$.

DETMANN, E.; VALADARES FILHO, S. C. On the estimation of non-fibrous carbohydrates in feeds and diets. Arquivo Brasileiro de Medicina Veterinária e Zootecnia, Belo Horizonte, v. 62, n. 4, p. 980-984, 2010.

DETMANN, E.; VALENTE, E. E. L.; BATISTA, E. D.; HUHTANEN, P. An evaluation of the performance and efficiency of nitrogen utilization in cattle fed tropical grass pastures with supplementation. Livestock Science, v. 162, n. 10, p. 141-153, 2014. Available at: $<$ http://www.sciencedirect.com/science/article/pii/ S1871141314000833>. Accessed at: 26 fev. 2016.

DOYLE, P. T.; FRANCIS, S. A.; STOCKDALE, C. R. Associative effects between feeds when concentrate supplements are fed to grazing dairy cows: a review of likely impacts on metabolisable energy supply. Australian Journal of Agricultural Research, v. 56, n. 12, p. 1315-1329, 2005. Available at: <http://www. publish.csiro.au/paper/AR05087.htm>. Accessed at: 26 fev. 2016.
FERREIRA, M. A.; VALADARES FILHO, S. C.; SILVA, L. F. C.; NASCIMENTO, F. B.; DETMANN, E.; VALADARES, R. F. D. Avaliação de indicadores em estudos com ruminantes: estimativas de consumos de concentrado e de silagem de milho por vacas em lactação. Revista Brasileira de Zootecnia, Viçosa, MG, v. 38, n. 8, p. 1574-1580, 2009.

GONZALES, F. H. D.; SCHEFFER, J. F. S. Perfil sanguíneo: ferramenta na análise clínica, metabólica e nutricional. Avaliação metabólica-nutricional de vacas leiteiras por meio de fluídos corporais. In: CONGRESSO BRASILEIRO DE MEDICINA VETERINÁRIA, 29., 2002, Gramado. Anais... Gramado: CONBRAVET, 2002. p. 5-17.

LOPES, S. A.; PAULINO, M. F.; DETMANN, E.; VALADARES FILHO, S. C.; VALENTE, E. E. L.; BARROS, L. V.; CARDENAS, J. E. G.; ALMEIDA, D. M.; MARTINS, L. S.; SILVA, A. G. Suplementation of suckling beef calves with different levels of crude protein on tropical pasture. Tropical Animal Health and Production, Netherlands, v. 45, n. 7, p. 379-384, 2013.

NATIONAL RESEARCH COUNCIL - NRC. Nutrients requirements of beef cattle. $7^{\text {th }}$ ed. Washington, D.C.: National Academy Press, 1996. 244 p.

PAULINO, M. F.; DETMANN, E.; SILVA, A. G.; ALMEIDA, D. M.; VALENTE, E. E. L.; MACIEL, I. F. S.; NASCIMENTO, J. L. M.; BITTENCOURT, J. A.; MARTINS, L. S.; BARROS, L. V.; PAULA, N. F.; MENDES, R. K. V.; LOPES, S. A.; CARVALHO, V. V. Bovinocultura de alto desempenho com sustentabilidade. In: SIMPÓSIO DE PRODUÇÃO DE GADO DE CORTE, 8., 2012, Viçosa, MG. Anais... Viçosa, MG: SIMCORTE, 2012. p. 183-196.

PAULINO, M. F.; DETMANN, E.; VALADARES FILHO, S. C. Suplementação animal em pasto: energética ou proteica? In: SIMPÓSIO SOBRE MANEJO ESTRATÉGICO DA PASTAGEM, 3., 2006, Viçosa, MG. Anais... Viçosa, MG: SIMFOR, 2006. p. 359-392.

PAULINO, M. F.; FIGUEIREDO, D. M.; MORAES, E. H. B. K.; PORTO, M. O.; SALES, M. F. L.; ACEDO, T. S.; VILLELA, S. D. J.; VALADARES FILHO, S. C. Suplementação de bovinos em pastagem: uma visão sistêmica. SIMPÓSIO DE PRODUÇÃO DE GADO DE CORTE, 4., 2004, Viçosa, MG. Anais... Viçosa, MG: SIMCORTE, 2004. p. 93-129.

PEREIRA, E. M.; SANTOS, F. A. P.; BITTAR, C. M. M.; RAMALHO, T. R.; COSTA, D. F. A.; MARTINEZ, J. C. Substituição do milho por farelo de trigo ou farelo de glúten de milho na ração de bovinos de corte em terminação. Acta Scientiarum Animal Sciences, Maringá, v. 29, n. 1, p. 49-55, 2007. 
PORTO, M. O.; PAULINO, M. F.; VALADARES FILHO, S. C.; DETMANN, E.; SALES, M. F. L.; COUTO, V. R. M. Fontes de energia em suplementos múltiplos para bezerros Nelore em creep-feeding: desempenho produtivo, consumo e digestibilidade de nutrientes. Revista Brasileira de Zootecnia, Viçosa, MG, v. 38, n. 7, p. 1329-1339, 2009.

SAMPAIO, C. B.; DETMANN, E.; LAZZARINI, I.; SOUZA, M. A.; PAULINO, M. F.; VALADARES FILHO, S. C. Rumen dynamics of neutral detergent fiber in cattle fed low-quality tropical forage and supplemented with nitrogenous compounds. Revista Brasileira de Zootecnia, Viçosa, MG, v. 38, n. 3, p. 560$569,2009$.

SAMPAIO, C. B.; DETMANN, E.; VALENTE, T. N. P.; SOUZA, M. A.; VALADARES FILHO, S. C.; PAULINO, M. F. Evaluation of fecal recovering and long term bias of internal and external markers in a digestion assay with cattle. Revista Brasileira de Zootecnia, Viçosa, MG, v. 40, n. 1, p. 174-182, 2011.
SILVA, L. F. C.; VALADARES FILHO, S. C.; CHIZZOTTI, M. L.; ROTTA, P. P.; PRADOS, L. F.; VALADARES, R. F. D.; ZANETTI, D.; BRAGA, J. M. S. Creatinine excretion and relationship with body weight of Nellore cattle. Revista Brasileira de Zootecnia, Viçosa, MG, v. 41, n. 3, p. 807-810, 2012.

TITGEMEYER, E. C.; ARMENDARIZ, C. K.; BINDEL, D. J.; GREENWOOD, R. H.; LOEST, C. A. Evaluation of titanium dioxide as a digestibility marker for cattle. Journal of Animal Science, Champaign, v. 79, n. 4, p. 1059-1063, 2001.

VALENTE, E. E. L.; PAULINO, M. F.; DETMANN, E.; VALADARES FILHO, S. C.; BARROS, L. V.; CABRAL, C. H. A.; SILVA, A. G.; DUARTE, M. S. Strategies of supplementation of female suckling calves and nutrition parameters of beef cows on tropical pasture. Tropical Animal Health and Production, Netherlands, v. 44, n. 7, p. 1803-1811, 2012.

VAN SOEST, P. J. Nutritional ecology of the ruminant. $2^{\text {th }}$ ed. Ithaca: Cornell University Press, 1994. 476 p. 
